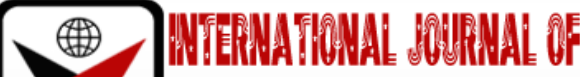

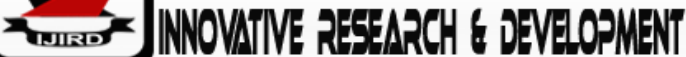

ISSN 2278-0211 (Online)

\section{Influence of School Facilities on Students' Academic Performance in Basic Science and Technology in Junior Secondary Schools in Osun State, Nigeria}

\author{
Olajide Simeon Olayinka \\ Lecturer, Institute of Education, Obafemi Awolowo University, Ile-Ife, Nigeria \\ Olanipekun Busayo Veronica \\ Lecturer, Department of Science Education, \\ Bamidele Olumilua University of Education Science and Technology, Nigeria \\ Obafunmilayo Adesewa Oluwadara \\ Graduate Student, Department of Science and Technology Education, \\ Obafemi Awolowo University, Ile-Ife, Nigeria
}

\begin{abstract}
:
The study investigated the influence of school facilities on students' academic performance in Basic Science and Technology in junior secondary schools in Osun state. It assessed school facilities available in junior secondary schools for the teaching and learning of Basic Science and Technology, determined the influence of school facilities on junior secondary school students' academic performance in Basic Science and Technology and finally examined the interaction effect of school facilities and gender on junior secondary schools students' academic performance in Basic Science and Technology with a view to providing information on the academic performance of students in the subject in the study area. The study adopted the descriptive survey research design. The population for the study comprised all junior secondary school two (JSS II) students of Basic Science and Technology in the state. Ten schools were selected from each of the three senatorial districts in the state using simple random sampling technique. From each of the selected schools, forty students were also selected using simple random sampling technique. In all, thirty schools and one thousand two hundred students constitute the sample size for the study. Two research Instruments were used to collect data for the study. They are: School Facilities Checklist (SFC) and Students' Previous School Term Results in Basic Science and Technology. Data collected were analyzed using frequency counts, simple percentages and regression analysis. The results of the study revealed a low level availability of school facilities for the teaching and learning of Basic Science and Technology such as science laboratories which are grossly inadequate 10(33.33\%), world globe 3 (10.00\%), computers 0 (0.00\%), electricity supply 7 (23.33\%), health care services0 (0.00\%), first aid box 9 (30.00\%)and so on. The results further showed a significant influence of school facilities on students' academic performance $(F=7.745<0.05)$ and the results finally revealed no significant interaction effect of school facilities and gender on students' academic performance in Basic Science and Technology ( F=5.361>0.05). The study concluded that school physical facilities are crucial to students' academic performance in Basic Science and Technology.
\end{abstract}

Keywords: School facilities, Performance, Basic Science and Technology

\section{Introduction}

An effective school facility is responsive to the changing programmes of educational delivery and at a minimum, should provide a physical environment that is comfortable, safe, secure, accessible, well illuminated, well ventilated, and aesthetically pleasing. The school facility consists of not only the physical structure and the varieties of building systems, such as mechanical, plumbing, electrical and power, telecommunications, security, and fire suppression systems. The facility also includes furnishings, materials and supplies, equipment and information technology as well as various aspects of the building grounds, namely, athletic fields, playgrounds, areas for outdoor learning, and vehicular access and parking. The school facility is much more than a passive container of the educational process: it is, rather, an integral component of the conditions of learning.

School facilities provide a real classroom experience for the learners and make teaching and learning process more interesting. In order to achieve good academic quality, some factors are pointed out as they relate to school facilities. The establishment of guidance and counseling services for students in their intellectual, social and employment pursuits is important. This is further backup with remedial, compensatory and testing programmes. Also important is the enrichment of school environment through the provision of well stocked libraries. Library facilities for these schools as a whole for the different care streams would also be germane (Broorde, 2003; Ezeanichinedu, 2009\&Onwurah, 2004). In all human 
society and throughout the history of mankind, education has assumed various roles and significance and has been used as an instrument for achieving various goals and objectives for the benefits of the society, which is also an instrument of change through an effective utilization of educational resources. Educational resources are; human, financial, material or physical, and education resources centers which constitute strategic factor in the functioning of any educational system. The success of such system depends much on the availability of school facilities and their level of utilization. Without them, it will be very difficult to have an effective system of education.

According to Olajide and Aladejana, (2019), academic performance is the outcome or output measure of a learner as a result of all that has been achieved or acquired in the course of training and experience in school environment. These performances can either be positively or negatively demonstrated due to various factors which include the availability or non-availability of school facilities.

According to Broorde (2003), school facilities are the sum total of the input that goes into the school system. They are all the things that are used directly or indirectly for the purpose of supporting, facilitating, influencing, transmitting or acquiring of knowledge, competence and skill by the learners. Essentially, school facilities are used for transmission of knowledge and aiding the education and training of the learners.

According to Onwurah (2004), the management of school physical facilities implies the application of the theory, principles and practices of management to ensure that all the necessary physical facilities in the school system are available in required number and are properly maintained. The school physical facilities help teacher and the students to be able to marry the theories being taught in classroom with a practical experience provided by such facilities.

According to the policy document pointed out by Agun (2009), education is an expensive social service and the successful implementation of educational programmes requires vocational workshops for the junior secondary schools and suitable textbooks, libraries and staff in all educational institutions which include the secondary school system. Also, Education Resources Centre is to be established at state and Federal levels (FRN, 2004). Quite often, the availability of school facilities will invariably influence positively the academic performance of students. This is considered as a direct variable. The discussion so far shows that material resources especially plant facilities are very important in the education system. Although, since the inception of formal education in Nigeria, material resources have been inadequate. The inadequacy affects the academic performance negatively and it leads to the falling standard of education in the country up till date. Thus, splendid building and materials which might involve substantial resources, modest buildings that are conducive to learning should be in place so as to improve students' academic performance.

It is however very obvious that both in rural and urban centres, there are many social services or school facilities that should be provided by the government for the improvement of students' academic performance. These school facilities are health service, conducive school buildings, library, laboratory, water supply, electricity, guidance and counseling services, sports and recreation, transportation, feeding and catering and the likes. These school facilities are basic needs of life, which improve the academic standard of students. Socially, these services need to be provided by the government to the school authority or by voluntary agencies for the betterment of students' results. In a situation where a particular school lacks most of these facilities, they may have to look for an alternative because the services are not only part of human survival but are very imperative for the development of a particular society. Furthermore, the school facilities not only bring comfort to learners, they also make learning more meaningful and interesting. However, these facilities are also very important to social, economic, cultural and political developments of any nation. It is pertinent to note that the availability of these facilities is an essential part of human existence.

Gender refers to socially constructed differences between male and female. Scholars, policymakers, and practitioners have observed and seem to agree upon socially constructed differences between male and female and its significant effects in their lives. Studies conducted across the world among the students studying in different levels found a significant gender difference in academic performance. Several studies have reported that female students outperform their male counterparts (Orabi, 2007; Dayioglu \& Turut, 2007; Khwaileh \& Zaza, 2010). Ghazvini \& Khajehpour (2011) further argued that even gender exists at the level of cognitive functioning in the academic environment. Girls are likely to be more adaptive in learning in a different environment. However, Wangu (2014) in a study conducted among the students of secondary schools in Kenya observed boys passing more than girls. On the other hand, Goni, Yaganawali, Ali, Bularafa, (2015) in a study conducted among college-going students did not observe the significant gender difference in academic performance.

\subsection{Statement of the Problem}

Investigations have shown that junior secondary schools students performed poorly in both internal and external Basic Science and Technology Examinations. This may not be unconnected with the non-availability of school facilities that could enhance students' academic performance in the subject. Hence, there is need to investigate the influence that school facilities may have on the academic performance of junior secondary school students in Basic Science and Technology in Osun State.

\subsection{Purpose of the Study}

The main purpose of the study is to investigate the influence of school facilities on students' academic performance in Basic Science and Technology in junior secondary schools in Osun State. The specific objectives of the study are to:

- Assess school facilities available in junior secondary schools in osun state for the teaching and learning of basic science and technology;

- Determine the influence of school facilities on junior secondary school students' academic performance in basic 
science and technology in the state; and

- Examine the interaction effects of school facilities and gender on junior secondary school students' academic performance in basic science and technology in the study area.

\subsection{Research Question}

What are the school facilities available in junior secondary schools for the teaching and learning of Basic Science and Technology?

\subsection{Hypotheses}

- Ho1. There is no significant influence of school facilities on junior secondary school students' academic performance in Basic Science and Technology

- Ho2. There is no significant interaction effect of school facilities and gender on junior secondary school students' academic performance in Basic Science and Technology

\section{Methodology}

The study employed a descriptive survey correlational research design. The population for the study comprised all junior secondary school students of Basic Science and Technology in Osun State. Ten junior secondary schools were randomly selected using simple random sampling technique from each of the senatorial districts in the state. From each of the selected schools, forty students were selected using simple random sampling technique to take part in the study. In all, thirty schools and one thousand and two hundred students were used for the study. Two research instruments were used to collect data for the study. They are: School Facilities Checklist (SFC) and Students' Previous School Term Results in Basic Science and Technology. Data collected were analyzed using frequency counts, simple percentages and regression analysis.

\section{Results}

\subsection{Research Question}

What are the school facilities available in junior secondary schools for the teaching and learning of Basic Science and Technology?

In order to answer this research question, data collected on the various school facilities available for the teaching and learning of Basic Science and Technology in junior secondary schools were subjected to descriptive statistics and the results are presented in the table below

\begin{tabular}{|c|c|c|c|}
\hline S/N & Facility & Available and Functioning f(\%) & Not Available f(\%) \\
\hline 1 & Classrooms & $45(75.00)$ & $15(25.00)$ \\
\hline 2 & Desks and seats & $755(62.92)$ & $445(37.08)$ \\
\hline 3 & Chalkboards or whiteboards & $54(90.00)$ & $6(10.00)$ \\
\hline 4 & Electricity & $7(23.33)$ & $23(76.67)$ \\
\hline 5 & Water supply & $6(20.00)$ & $24(80.00)$ \\
\hline 6 & Library & $13(43.33)$ & $17(563.67)$ \\
\hline 7 & Science laboratory & $10(33.33)$ & $20(66.67)$ \\
\hline 8 & Globe & $3(10.00)$ & $21(90.00)$ \\
\hline 9 & First aid box & $9(30.00)$ & $18(60.00)$ \\
\hline 10 & Safety and security & $12(40.00)$ & $30(100.00)$ \\
\hline 11 & Health care centre & $0(0.00)$ & $3(10.00)$ \\
\hline 12 & Sport field & $27(90.00)$ & $20(66.67)$ \\
\hline 13 & Bulletin board & $10(33.33)$ & $30(100.00)$ \\
\hline 14 & Computers & $0(0.00)$ & $26(86.67)$ \\
\hline 15 & School bus & $4(13.33)$ & \\
\hline
\end{tabular}

Table 1: Descriptive Statistics of the School Facilities Available for the Teaching and Learning of Basic Science and Technology in Junior Secondary Schools

From the table above, it was evident that electricity (23.33\%), water supply (20.00\%), library (43.33\%), laboratory (33.33\%), world globe $(10.00 \%)$, first aid box $(30.00 \%)$, health care services $(0.00 \%)$ and computers $(0.00 \%)$ are scarcely provided in schools for the teaching and learning of Basic Science and Technology in the state which may likely hinder effective learning of the subject in schools. The highest proportions of those facilities are not supplied to schools as seen in the table.

\subsubsection{Hypothesis One}

There is no significant influence of school facilities on junior secondary school students' academic performance in Basic Science and Technology.

In order to test this hypothesis, data collected on school facilities and students' performance in Basic Science and Technology were subjected to regression analysis and the results are presented in the Table below. 


\begin{tabular}{|c|c|c|c|c|c|}
\hline $\begin{array}{c}\mathbf{R}=\mathbf{0 . 7 2 3} \\
\mathbf{R}^{2}=\mathbf{0 . 8 0 4} \\
\text { Adj. R= 0.416 } \\
\mathbf{F = 7 . 7 4 5}\end{array}$ & \multicolumn{2}{|c|}{$\begin{array}{c}\text { Unstandardized } \\
\text { Coefficients }\end{array}$} & $\begin{array}{c}\text { Standardized } \\
\text { Coefficients }\end{array}$ & & \\
\cline { 2 - 6 } & $\mathbf{B}$ & Std. Error & Beta & $\mathbf{T}$ & Sig \\
\hline (constant) & 45.316 & 6.241 & & 3.358 & 0.001 \\
\hline School facilities & 0.942 & 0.147 & 0.812 & 2.941 & 0.017 \\
\hline
\end{tabular}

Table 2: Regression Analysis of the Influence of School Facilities on Junior Secondary

School Students' Academic Performance in Basic Science and Technology

a. Dependent Variable; Academic Performance

b. Predictor: (Constant), School Facilities

Results in Table 2 showed that there was significant influence of school facilities on junior secondary school students' academic performance in Basic Science and Technology Osun State $(F=7.745 ; p<0.05)$. Therefore, the null hypothesis that states that there is no significant influence of school facilities on junior secondary school students' academic performance in Basic Science and Technology in the study area is hereby rejected.

\subsubsection{Hypothesis Two}

There is no significant interaction effect of school facilities and gender on junior secondary school students' academic performance in Basic Science and Technology

In order to test this hypothesis, data collected on school facilities and students' academic performance in Basic Science and Technology based on gender were subjected to regression analysis and the results are presented in the Table below.

\begin{tabular}{|c|c|c|c|c|c|}
\hline $\mathbf{R}=\mathbf{0 . 0 3 1}$ & \multicolumn{2}{|c|}{ Unstandardized Coefficients } & Standardized Coefficients & & \\
\cline { 2 - 6 } $\mathbf{R}^{2}=\mathbf{0 . 0 0 4}$ \\
$\begin{array}{c}\text { Adj. } \mathbf{R}^{2}=\mathbf{0 . 0 3 6} \\
\mathbf{F = 5 . 3 6 1}\end{array}$ & & Std. Error & Beta & $\mathbf{T}$ & Sig \\
\hline (constant) & -7.331 & 44.416 & & & \\
\hline School facilities & 0.756 & 0.146 & & 6.111 & 0.071 \\
\hline Gender & 0.074 & 0.148 & 0.294 & 0.234 & 0.672 \\
\hline
\end{tabular}

Table 3: Regression Analysis Showing The Interaction Effect of School Facilities and Gender on Junior Secondary School Students' Academic Performance in Basic Science and Technology in the Study Area

a. Dependent Variable; Academic Performance

b. Predictor: (Constant), School Facilities, Gender

Results in Table 3 showed no significant interaction effect of school facilities and gender on junior secondary school students' academic performance in Basic Science and Technology $(F=5.361 ; p>0.05)$. Hence, the null hypothesis that states that there is no $\mathrm{f}$ (significant interaction effect of school facilities and gender on junior secondary school students' academic performance in Basic Science and Technology is hereby not rejected.

\section{Discussion of Findings}

Findings of the study showed that school facilities were scarcely available for effective teaching and learning of Basic Science and Technology in junior secondary schools in the state. The findings which support the earlier findings of Aguokogbuo, (2000), Ani, (2007) and Brown, (1997). The results of the study also revealed that school facilities had a greater influence on junior secondary school students' academic performance in Basic Science and Technology in Osun State. The results which corroborate with the findings of Ani (2007), Bullock (2007) and Agun (2009) when they found out a significant relationship between school physical facilities and students' achievement in school subjects. The results further support the findings of Fakomogbon (2004) and Ezeanichinedu (2009).

The results of the study further revealed no significant interaction effect of school facilities and gender on students' academic performance in Basic Science and Technology in the study area. The results which differ from those of Zembar and Blume (2011) who stated that girls rather than boys achieve better in schools; which agrees with Dayioglu and Turut-Asit (2004) who also attested to the fact that girls do better than boysin school. Ghazvini \& Khajehpour (2011) further argued that even gender exists at the level of cognitive functioning in the academic environment. Girls are likely to be more adaptive in learning in a different environment. However, Wangu (2014) in a study conducted among the students of secondary schools in Kenya observed boys passing more than girls. However, the findings were in line with the results of Abubakkar and Dokubo (2011) and Uduosoro (2011) who found no significant difference in the achievement of boys and girls in Mathematics. Furthermore, the results corroborate the findings of Goni et al. (2015) in a study conducted among college-going students where no significant gender difference was observed in academic performance.

\section{Conclusion}

The study has found out that school facilities play vital roles on the academic performance of students. Government and other stakeholders in education must ensure that necessary and relevant school facilities are put in place for effective and meaningful teaching and learning in schools. 


\section{References}

i. Abraham, M. (2003). Educational administration in Nigeria. Port Harcourt: Pan Unique Publishing Co, Ltd.

ii. Abubakkar, R.B, and Dokubo, 0.0. (2011). Age and gender as creditors of academy achievement of college mathematics and science students proceeding of the 2011 international conference on teaching, learningand change

iii. Adesina, S. (1984). Introduction to Educational Planning. Ile-Ife; University of Ife press Ltd. Afolabi, M. (1998). Introduction to Research Methods for Writing Proposals. Zaria: Alpha Publishers.

iv. Agun, J. E. (2009). Total Materials Management Achieving Maximum Profit Through Materials Operations, 2nd ed. Boston: Kluwer Academic publishers

v. Aguokogbuo, A. O. (2000). Maintaining School Facilities for Achievement of Universal Basic Education (UBE) Objectives in Management of Primary and Secondary Education in Nigeria.

vi. Ani, C. I. (2007).Procurement, management and maintenance of the school plant A. N. Ndu, L.O. Ocho, and B. S. Okeke (Eds). Dynamics of educational administration and management. The Nigerian perceptive. Awka: Meks Publishers Ltd.

vii. Broorde, C. A. (2003). The Relationship between Design of School Facilities and Student Behaviour and Academic Achievement. (Doctoral Dissertation, University of Mississippi). Retrieved May 2, 2008, from ProQuest Digital; Dissertations Database. (AAT 3089830).

viii. Brown, J. W. (1997). Effects of Maintenance of School Physical Facilities and Environment on Students' Learning. Educational Facility Planners, 27(1): 28-29.

ix. Dayioglu, M. \& Turut-Asik (2004). Gender Differences in Academic Performance in a Large Public University in Turkey ERC Walking Papers in Economy.

x. Ezeanichinedu, D. C. (2009) Supervision, facilities utilization and students' academic performance. Unpublished M. Edproject. University of Ilorin.

xi. Fakomogbon, A. A. (2004). Management physical resources for academic effectiveness University Ilorin journal of Education, 1(4), 16

xii. Goni, U., Yaganawali S.B., Ali, H.K., Bularafa, M.W. (2015). Gender differences in students' academic performance in Borno State, Nigeria: Implications for counseling. Journal of Education and Practice, 6(32):107-114.

xiii. Federal Republic of Nigeria (2004). National policy on Education: Abuja; NERDC

xiv. Hannele, F, kaarina, K, Seija, S, (2002) A good school Library. The Finnish National Board of Education. Finland.

xV. Ghazvini, S.D. and Khajehpour, M. (2011). Gender differences in factors affecting academic performance of high school students. Procedia - Social and Behavioral Sciences, 15: 1040-1045.

xvi. Hofstein A. and Lunetta V. N. (2002), The role of the laboratory in science teaching: neglected aspects of research, Review of Educational Research, 52, 201-217.

xvii. Khwaileh, F. and Zaza, H. (2010). Gender differences in academic performance among undergraduates at the University of Jordan: Are they real or stereotyping? College Student Journal, 45.

xviii. Mankumari, P. \& Ajay, T. (2017) Gender Differences in the Academic Performance of Students. Journal of Development and Social Engineering Volume 3 | Number 1 | December 2017, 39-47

xix. Olajide, S. O. \& Aladejana, F.O. (2019) Comparative Effectiveness of Three Active Learning Strategies in Transforming Learners' Outcomes in Basic Science for Social Change in Osun State. IOSR Journal of Humanities and Social Science. Vol. 24 Issue 8. Pp36-41

xx. Olutola, A. D. (1998). Educational Facilities and Student Performance in WASC Examination. Journal of Educational Management 1(1), 17-25.

xxi. Onwurah, C. (2004). School plant management. In T.O. Mgbodile (Ed). Fundamentals in educational administration and planning. Enugu: Magnet Computer Services.

xxii. Orabi, I. (2007). Gender differences in student academic performance and attitudes. American Society for Engineering Education (Available at https://peer.asee.org/gender-differences-in-student-academicperformance-and-attitudes. pdf)

xxiii. Uduosoro, U.J (2011). The Effect of Gender and Mathematics Ability on Academic Performance of Students in Chemistry. African Research Review

xxiv. Wangu, M.J. (2014). The impact of gender differences on student's academic performance in secondary schools in Ndumberi division, Kiambucounty, Kenya in science subjects and languages. A Research Project Submitted In Partial Fulfillment Of The Requirement For The Award Of The Postgraduate Diploma In Education Of University Of Nairobi. (Available at http://erepository.uonbi. ac.ke).

xxv. Zembar, L. B. \& Blume, L. B (2011). Gender and Academic Achievement. www.Education .Com 